\title{
Bio-based textile processing through the application of enzymes for environmental sustainability
}

\begin{abstract}
Textile industries contribute significantly to the economy of many developing countries. Every year, these countries export millions of dollars' worth of textile products to developed countries. However, textile industries use expensive and corrosive chemicals that pose a significant threat to environmental quality and public health. This has led to serious concerns and necessitated the inclusion of safer and environmentally friendly alternatives. Consequently, bio-based processing has created a new approach utilizing biotechnological advances. This article uses evidence from the scientific literature to examine the application of industrial biotechnology in textile-processing industries, which includes enzymes, as a sustainable alternative to the harsh toxic chemicals currently used in textile processing. The article draws on evidence that enzymes offer a competitive advantage over chemicals with less resource requirements (energy and water), reduced emission and less waste. Due to high specificity, enzymes produce minimum byproducts. The implementation of enzymes in textile processing could offer environmental benefits, and improve public health and the sustainability of textiles and apparel. This article contributes to critical awareness by providing succinct information about major enzymes used in textile processes to improve the performance of textile materials, thus contributing to changes in behaviours and
\end{abstract}


attitudes towards textile processing and environmental sustainability. This can assist textile manufacturers and governments in the developing world in campaigns to promote biotechnologies for environmental sustainability.

\section{Keywords}

biotechnology

textile

enzyme

sustainable technology

environmental sustainability

developing countries

\section{Introduction}

Recent developments in industrial biotechnology have offered eco-friendly approaches without compromising production efficiency and product quality at industrial settings. Industrial biotechnology encompasses the use of enzymes and defined micro-organisms for goods and services (OECD 2001; Jørgensen et al. 2006). Enzymes are observed to have increasing 
applications in many industrial processes and have evolved into a multibillion-dollar business following the rapid growth of the global market for industrial enzymes (Sarmiento et al. 2015). Despite the presence of enzymes in all living entities, most of the enzymes in industrial use are of microbial origin. Industrial enzymes have found their applications in different sectors including leather, tanning, textile, pulp and paper, chemical and pharmaceutical, food, detergent and starch industries, among others ( $\mathrm{Li}$ et al. 2012; Sarmiento et al. 2015).

Approximately 10 per cent of industrial enzymes account for textile processing (Silva et al. 2010; Choudhury 2014). Textile fibres and fabrics undergo a number of long production and manufacturing processes before they can be used for preparing garments or apparel. Textile-wet preparatory processes, which consist of scouring, bleaching, colouration and finishing, are carried out in water-based systems deemed indispensable for improving the performance and utility of textile materials (Kumar and Gunasundari 2018). Almost all dyes, specialty chemicals and finishing chemicals used in the textile applications are incorporated into the textile substrates from a water bath, either through solution, dispersion or emulsion. In textile-wet processing, water serves mainly two purposes: as a medium for handling and using chemicals and second, as a solvent for washing and rinsing the textile materials. The wet processing of textiles places a heavy burden on the use of water and energy. In addition, textile industries employ a variety of chemicals from the early stage of processing through to the stage of finished products. These chemicals are expensive and pose a significant threat to environmental quality, the ecosystem and aquifers, and to the health of manufacturing workers (Shen and Smith 2015; Saxena et al. 2017; Kumar and Gunasundari 2018). This has caused serious concern and necessitated the inclusion of safer and environmentally friendly, green alternatives. Consumer demand has heightened preference for sustainable textile materials and apparel (Gwozdz et al. 2017). Consequently, bio-based processing 
presents a significant potential for replacing harmful chemicals with materials requiring less water and energy, thus contributing to the production of sustainable textile materials (Maiti et al. 2018).

The textile and clothing industry is a major part of manufacturing and trade in many developing countries. These countries have taken advantage of the relative ease of entry into this field while high wages in developed countries have lost them the comparative advantage of the manufacturing and subsequent exportation of textiles and apparels. However, there is more to textile production than price-competitiveness. Concern with the issue of environmental sustainability and regulatory and policy regimes would impose stringent ecological constraints on textile processing that would not, however, compromise the quality-competitiveness of the final product. Biotechnological processes can, in this respect, contribute significantly to eco-friendly manufacturing by replacing traditional textile production systems.

This article addresses the following research questions: what is the scientific argument supporting the effectiveness of biotechnology in textile processing? To what extent can the use of biotechnology, particularly enzyme processing, bring about greener alternatives in textile industries? Based on the scientific literature, we discuss the benefits and issues associated with enzymatic processing with the aim of raising awareness among stakeholders about how biotechnology could help environmental sustainability in the developing world. In answering these research questions, we focus the analysis on five key biotechnologies in textile: bio-desizing, bioscouring, bio-bleaching, bio-finishing and bio-stoning or denim bio-wash. The aim is to break complex scientific information into information that is intelligible to various stakeholders. The focus of the article on these five aspects is linked to the fact that they are novel, and information about them and their application is only emerging in the developing world. 


\section{Methodology}

The article draws on relevant data and information from the existing body scientific literature to examine the potency of the use of enzymatic processing for environmental sustainability in the textile industry. This departs from the 'traditional hypothetico-deductive approach' to exploit the potency of secondary data in constructing a critical argument (Dana and Dana 2005). We first located the literature that addresses important developments in biotechnology that are geared to resolving some of the negative environmental impact of traditional processing in the textile industry. We then provided a discussion of the main findings supporting the use of enzymatic processing and biotechnology, categorizing the benefits but also dialectically establishing the issues associated with the use of biotechnology. Thus, our two-way approach expands 'the exploration of plausible rival hypotheses, process tracing and counterfactual reasoning' (Dana 2015:154.) in the debate about the use of biotechnology in enhancing the benefits associated with enzymatic treatment in textiles for environmental sustainability in developing countries.

\section{Perspectives on enzymes in textile wet processing}

Enzymes are biological catalysts that are responsible for performing specific chemical reactions. They usually require comparative mild conditions for their operation. All enzymes are proteins in nature and decompose after their lifetime (Shen and Smith 2015). Some enzymes require specific small non-protein molecules, known as cofactors, to function as catalysts. The reaction specificity of the enzymes could be used for targeted textile applications without undesirable effects (Shen 2009). Commercially enzymes are usually manufactured by fermentation from three primary sources: animal tissues, plants and microbes. Enzymes are classified as oxidoreductases, 
transferases, hydrolases, lyases, isomerases and ligases (Choudhury 2014). Most enzymes used in textile wet processing are hydrolases, which are responsible for catalysing hydrolysis of chemical bonds. This group comprises of amylases, cellulases, pectinases, catalases and proteases, which are used in various textile manufacturing processes. However, laccases and peroxidases belonging to the oxidoreductase group have found interesting textile applications that include decolourizing textile effluents, bleaching textiles, modification towards the surface of the fabrics and synthesis of dyes (Shen and Smith 2015). Specific enzymes, used alone or in combination with other enzymes for textile applications, are shown in Table 1.

\section{TABLE 1 HERE...}

\subsection{Bio-desizing}

De-sizing is a process that involves the removal of size from woven cotton fabric. The most common sizes are organic compounds such as starch and its derivatives, cellulose derivatives, polyacrylates and polyvinyl alcohol. Their role is to provide a protective coating on yarns during weaving. It is essential that after weaving, the size must be removed before dyeing and finishing. It is usually accomplished by treating the fabric with chemicals such as acids, bases or oxidizing agents (Aly et al. 2010). The de-sizing effluents contain high organics with Chemical Oxygen Demand (COD), which comprise approximately 60 per cent of the total organic load of effluents generated from the textile-processing industries (Parmar and Shukla 2016). Amylase enzymes are the major enzymes used for de-sizing in these industries and can be regarded as the main application of amylases for the enzymatic de-sizing processes or bio-desizing (Araujo et al. 2008; 
Choudhury 2014). Based on the degradation mechanism, amylases are grouped into $\alpha$-amylases (dextrinogenic) and $\beta$-amylases (saccharogenic). The $\alpha$-amylases cleave at random locations on the starch molecule to produce maltose from amylose, or maltose and glucose from amylopection, while $\beta$-amylases produce maltose by a stepwise hydrolysis reaction. As $\alpha$-amylases tend to be faster-acting than $\beta$-amylases and because of their ability to act anywhere on the substrate molecule, they are used for textile de-sizing (Regan 1962; Sojka-Ledakowicz et al. 2006; Hossain and Uddin 2011; Mojsov 2011). These enzymes catalyse the hydrolysis of water-insoluble starch to water-soluble end-products and could be easily removed from cotton in the subsequent washing steps (Opwis et al. 2010; Shahid et al. 2016).

The temperature requirement for de-sizing is usually at least $70^{\circ} \mathrm{C}$, and higher temperatures are preferred (Shahid et al. 2016). A regular amaylase works at a temperature range of $25-55^{\circ} \mathrm{C}$ while medium-temperature-range amylases can be used in the range of $50-95^{\circ} \mathrm{C}$. The availability of amylase preparations active at these temperatures has opened up the possibility of performing bio-desizing at temperatures higher than $70^{\circ} \mathrm{C}$ (Ando et al. 2002). Thermo-stable amylases can be used at temperatures above $95^{\circ} \mathrm{C}$ in continuous pretreatment de-sizing (Choudhury 2014). In addition, modified amylases with improved performance, e.g. thermo-stable, could be developed by different protein-engineering methods, including random mutagenesis, homology considerations, site-directed mutagenesis, etc. Examples include $\alpha$-amylases, which have been isolated from bacterial sources and subsequently characterized. These modified amylases, which have achieved higher heat stability, show activity over broader ranges of $\mathrm{pH}$ and show excellent potential in de-sizing (Diderichsen 1995; Shahid et al. 2016).

Higher de-sizing is achieved with thermo-stable enzymes, which improves the swelling of the fabric and subsequent absorption. The enzymes isolated from micro-organisms in extreme 
environments are naturally adapted to catalyse reactions under harsh conditions of temperature and $\mathrm{pH}$, and can serve as better alternatives for industrial uses (Sharma and Satyanarayana 2013). Therefore, it is important that rational selection of micro-organisms from cold, moderate and extremely hot environments is adopted to produce desizing enzyme preparations with appropriate activities (Bertoldo and Antranikian 2002; Siddiqui 2015). Amylases from micro-organisms that thrive at relatively high temperatures have gained wider acceptance due to their shortened processing time on industrial scales. This has led to efficient industrial processes with improved absorbency over their mesophilic counterparts and conventional processes. De-sizing with lowtemperature $\alpha$-amylases $\left(20-60{ }^{\circ} \mathrm{C}\right)$ takes more time than high-temperature amylases $\left(95-100{ }^{\circ} \mathrm{C}\right.$ or higher). In addition, de-sizing with high-temperature amylases can be performed in steam chambers to allow a fully continuous process (Shahid et al. 2016). Therefore, as raising the temperature for de-sizing facilitates efficient starch removal and reduces process duration, amylases from the high-temperature micro-organisms have gained wider acceptance (Saravanan et al. 2011).

Enzymatic de-sizing or biodesizing generates various types of simple sugars as end products. The sugars are nontoxic but influence the biological oxygen demand (BOD) of the wastewater in a negative manner. The de-sizing process consists of three main stages: impregnation, incubation and after-wash. Pre-wash is carried out to remove non-starch watersoluble additives from the fabric and facilitate the binding of amylase to the starch molecules. The starch is sequentially wetted and heated to gelatinize so that better contact between the enzyme and the substrate can be established. Impregnation takes place at temperatures above $70^{\circ} \mathrm{C}$ in a calcium-containing buffered solution. On the other hand, a longer incubation period at a lower temperature is required to soak the fabric with the enzyme solution at the optimum temperature. 
The duration of the incubation period ranges from 2 to 16 hours and the variations of the incubation period are governed by several factors, including the stability and the activity of the enzyme relative to the processing temperature and the $\mathrm{pH}$, size and nature of the fabric. During this period, wetting agents and nonionic surfactants could be employed to facilitate proper enzyme penetration and absorption, fibre swelling, and remove waxes, soils and synthetic sizing agents from the fabrics. Subsequently, the fabrics should be cleaned above $80^{\circ} \mathrm{C}$ in alkaline liquor and then washed off in neutral liquor. The sized yarns are then dried, followed by the occasional addition of beef or other fat in the size bath. This increases the smoothness of the sized yarn. Lipase enzymes are also added along with amylases into the de-sizing bath to remove fats. The addition of other enzymes into the process assists in efficient de-sizing due to the synergistic effects and removes natural impurities from the cellulosic materials (Choudhury 2014). The hydrophobic part of the size that arises from the addition of fat-based lubricants is efficiently removed by the lipases. These lubricants are difficult to eliminate even in scouring. Improved de-sizing has the advantages of shortening the processing time and thereby helps produce a higher quality end product in terms of the uniformity and the feel of the fabric against the skin (Madhu and Chakraborty 2017). Similarly, incorporation of peroxide or neutral cellulase with commercial amylase shows better wettability, higher dye uptake and lower stiffness (Ibrahim et al. 2004). Furthermore, glucoamylase in combination with $\alpha$-amylase could be employed to carry out simultaneous de-sizing and acid demineralization in the case of cotton fabrics. This removes earth alkalis and cationic metal particles efficiently from cotton fabric and improves the de-sizing performance over normal washing or treatment in alkali.

\subsection{Bio-scouring}


The outer cuticle and primary walls of cellulosic fibres contain varying proportions of pectin, waxes, fats, proteinaceous materials, etc. These non-cellulosic impurities render improper dyeing and finishing of the cellulosic fibres because of poor wettability and dirty appearance. Primary cell non-cellulosic compounds remain inaccessible due to the presence of waxes in the thin outer wall (Hardin 2010; Madhu and Chakraborty 2017). It is necessary to remove the waxes for subsequent processing. These hydrophobic non-cellulosic components are usually eliminated by a hot aqueous alkaline scouring process so that the wettability of the fibre can be improved, which in turn ultimately facilitates uniform dyeing and finishing. However, the effectiveness of alkaline scouring in achieving satisfactory wettability is limited by the fact that it is resource-intensive and needs to be carried out at higher $\mathrm{pH}$ and temperature. The bio-scouring of cotton with enzymes has shown excellent promise as they tend to operate over a much broader range of $\mathrm{pH}$ and at lower temperatures (Hartzell and You-Lo 1998; Shahid et al. 2016). The requirement of less energy in bio-scouring in comparison with the conventional approach of scouring has rendered bio-scouring an eco-friendly approach. It is specific in targeting the non-cellulosic impurities and does not alter the substrate. As a result, cotton fibre can retain its inherent properties and the fabric remains softer to the touch after processing. Bio-scouring can also be used for blending cotton with silk, wool and cashmere as the severe alkaline conditions of classic scouring compromise the quality of these fibres (Csiszar et al. 2001; Sojka-Ledakowicz et al. 2006; Wang et al. 2007a; Madhu and Chakraborty 2017).

Followed by the removal of waxes from the outer wall, pectin remains the major noncellulosic substance in cotton. It acts as the cementing or adhesive material between cellulosic and non-cellulosic substances. Therefore, the removal of pectin facilitates easy removal of the remaining non-cellulosic substances; hence, the process of bio-scouring is based on the concept of 
breakdown of pectin with the enzymes. The complex structure of pectin is broken down into simpler molecules by the enzymes broadly known as pectinases (Shahid et al. 2016; Madhu and Chakraborty 2017). Initially, bio-scouring was attempted with pectinases, proteases and lipases enzymes to remove the non-cellulosic impurities from the fibre. However, pectinases were found to be the most effective, followed by the lipases; the proteases were the least effective. This led scientists to characterize and optimize different pectinases for cotton fibre scouring.

The pectinases are usually effective in $\mathrm{pH} 5-9$ and whether the $\mathrm{pH}$ of the bath should be kept alkaline or acidic depends on the type of pectinase. Both types show similar scouring effects; however, acidic pectinases work in low concentrations. Acidic medium could degrade the pectin within the $\mathrm{pH}$ range of 4-6 without pectinase, and helps in the removal of pectin in this condition. Bio-scouring was initially limited by the longer incubation period; however, the introduction of new pectinase types and incorporation of additives into the processes have led to sustainable industrial processing (Sahin and Gursoy 2005; Presa and Tavcer 2008; Ismal 2008; Madhu and Chakraborty 2017). The addition of non-ionic surfactants was proven to be efficient for enzyme penetration as they tend to lower the surface tension of fibres and aid the removal of wax and greasy material (Buchert et al. 2000; Traore and Buschle-Diller, 2000). In line with these efforts to work under higher temperature and alkaline conditions, a genetic modification technique was employed to produce a novel pectinase for bio-scouring with low dose requirements (Solbak et al. 2005). The synergistic effect of lipases in combination with pectinase was found to be effective as it increased the hydrophilicity of cellulosic textiles. Lipases were responsible for removing natural fats and lubricants to achieve better absorbency and enhance levelness in the processing of dyeing (Sangwatanaroj et al. 2003; Kalantzi et al. 2010; Madhu and Chakraborty 2017). Besides, cellulases were employed to hydrolyse cellulose chains for impurity removal (Ismal 2008; 
Saravanan et al. 2008). Mixed enzyme systems incorporating pectinase in combination with lipases, proteases, cellulases, xylanases or cutinases were found to be very effective for this purpose (Li and Hardin 1997; Karapinar and Sariisik 2004; Wang et al. 2007b; Agrawal et al. 2008; Vigneswaran et al. 2013). Sometimes, single-step scouring and bleaching were carried out together to minimize the use of energy and water resources. For example, the alkaline pectinase was coupled with peroxide bleaching and the dyeing process for single-bath de-sizing, bioscouring and bleaching of starch-sized cotton fabrics by a glucose-oxidase enzyme. The concurrent action of pectinase and peracetic acid was able to remove pectin and increase the degree of whiteness (Madhu and Chakraborty, 2017). Pectinases were also immobilized onto different platforms to achieve effective scouring over conventional alkaline processes or bio-scouring in aqueous media (Delcheva et al. 2007; Li et al. 2007). However, the availability of economically viable and commercial enzyme preparations either pectinases alone or in a mixture with other enzymes is below par for bio-scouring.

\subsection{Bio-bleaching}

Bleaching is considered to be one of the major steps of textile-wet processing prior to cotton dyeing. The natural pigments usually lead to a dirty appearance in the fibres after processing. The purpose of bleaching is to destroy or decolourize natural pigments present in the fibres to achieve a pure white appearance before dying. In the past, the fibres were treated with chlorine and oxidizing agents in extreme conditions to achieve whitening of fabrics. In recent times, hydrogen peroxide has been used more commonly at an industrial scale as a bleaching agent at alkaline $\mathrm{pH}$ and near boiling temperatures. The removal of residual hydrogen peroxide from fabrics requires a substantial amount of water, which constitutes a major problem in dyeing (Shahid et al. 2016). 
Moreover, the radical reactions on the surface of the fabrics decrease the degree of polymerization and cause damage to fibres (Basto et al. 2007; Madhu and Chakraborty 2017). A number of alternative methods for bleaching have been explored in the textile plants, e.g. enzymatic bleaching with laccase/mediator systems, glucose-oxidases, peroxidases and peracids in situ generated enzymatically. However, the bio-bleaching process with laccase/mediator systems has been reported to be very effective due to its specific action on coloured substances (Pereira et al. 2005; Spicka and Tavcer, 2013a, 2013b). The use of laccases has demonstrated that the enzymes decolourize or eliminate coloured flavonoids in cotton bleaching (Hadzhiyska et al. 2006; Kim et al. 2007;) by alteration of phenolic hydroxyl groups (Pereira et al. 2005; Gonçalves et al. 2014).

A short-duration laccase-mediated system pre-treatment prior to hydrogen peroxide bleaching enhances the whiteness of cotton fabrics along with a lower dose requirement for hydrogen peroxide at a reduced temperature (Tzanov et al. 2003a, 2003b). The combined method of laccase-hydrogen peroxide cotton bleaching with ultrasound energy also enhances bleaching efficiency in mild conditions of $\mathrm{pH} 5.0$ and $60^{\circ} \mathrm{C}$ for $30 \mathrm{~min}$ and remarkably improves product quality with the desired level of whiteness. Ultrasound energy has been reported to increase enzyme activity and improve the diffusion of the enzyme to the substrate surface (Abou-Okeil et al. 2010; Basto et al. 2007). Another enzyme, glucose oxidase (GOD), has shown great promise in cotton bleaching because of its specificity to produce hydrogen peroxide from glucose. This enzymatic system is quite unique in nature as it utilizes glucose in both desizing waste baths and scouring treatments, decreases water consumption and discharges less wastewater (Shahid et al. 2016). Reports show that combined one-bath desizing and bleaching or bleaching using reused desized bath produces better whiteness and improves mechanical properties like tensile and tear strength (Anis et al. 2009; Hebeish et al. 2013; Li and Hinks 2012). GOD produces hydrogen 
peroxide in slightly acidic to neutral conditions at low temperatures; however, bleaching requires high temperatures of $80-90^{\circ} \mathrm{C}$ and alkaline $\mathrm{pH} 11.0$ to produce desirable effects (Anis et al. 2009; Farooq et al. 2013; Ramadan 2008). A bio-bleaching system employing arylesterases and hydrogen peroxide has also been reported (Auterinen 2011).

If newly developed enzymatic processes could be used globally, it could save approximately 10 trillion litres of freshwater and reduce greenhouse gas emission by 30 million metric tonnes annually (Shahid et al. 2016).

\subsection{Bio-finishing}

Bio-finishing/bio-polishing is the process of fibre surface modification and eliminates hair-like micro, fuzzy fibrils from the fabric surfaces or yarn by cellulases either before or after dyeing (Araujo et al. 2008; Saravanan et al. 2009, Choudhury 2014). Enzyme action on the fabric surface provides a softer finish and improved appearance. A ball of fuzz is called a pill and can present a major quality problem because pills result in an unattractive knotty fabric appearance. Therefore, the main advantage of bio-polishing is the prevention of pilling. Furthermore, the removal of fuzz improves colour brightness, hand feel and water absorbance of fibres, and provides a cleaner surface structure (Ibrahim et al. 2011). Traditional approaches use to emit gases from combustion. Enzymatic bio-polishing is considered an environment-friendly approach as it replaces gas singeing and no emission occurs (Choudhury 2014).

In the event of bio-polishing, cellulosic fibres are enzymatically hydrolysed by the combined actions of three-component enzyme systems comprising endoglucanases (EG) or endocellulases, exoglucanases or cellobiohydrolases $(\mathrm{CBH})$ and cellobiases or $\beta$-glucosidases (Saravanan et al. 2009). In nature, cellulolytic systems exist in differential compositions in 
different cellulase preparations and work in a synergistic fashion. EGs cleave bonds along the length of cellulose chains in the middle of the amorphous region; CBHs work in the crystalline ends of cellulose chains and produce primarily cellobiose. Finally, $\beta$-glucosidases break cellobiose and soluble oligosaccharides into glucose (Madhu and Chakraborty 2017). The first reported commercially available cellulases for bio-polishing contain a combination of EGs, CBHs and cellobiases. They displayed the capacity to work on cellulosic fibres in a controlled and desired manner (Cavaco-Paulo 1998). A number of cellulosic fibre pre- and post-treatment methods are employed to enhance the efficiency of bio-polishing, such as soaking in water for a few hours and steaming prior to the enzymatic treatment (Pere et al. 2001). These methods improve the hydrolytic activity of cellulases on the fibres. In particular, steaming markedly enhances EGs' activity due to the swelling of less ordered sites on the fibre wall. Types of cellulases based on different types of cellulosic substrates, the optimization of process parameters and enzyme concentration are crucial to achieve effective bio-polishing. For example, acid cellulases-enriched EGs show effective biopolishing of cellulosics (Bahtiyari and Duran 2010; Uddin 2010; Bai et al. 2012; Saravanan et al. 2013; Mojsov 2014).

The attachment of cellulases onto immobilization platforms offers the possibility of manipulating the action of the enzymes and its action on the fibre surface can be controlled. Various methods and immobilization matrices are used to attach cellulases to improve thermal stability and offer the potential to facilitate the reuse of the enzymes (Hirsh et al. 2010; Yin et al. 2013; Romo-Sanchez et al. 2014). Textile-specific application includes immobilization of acidic cellulases onto specific functionalized matrices, which improves the stability at neutral pH (Dincer and Telefoncu 2007), and commercial cellulases immobilized onto epoxy resins show better integrity of the enzyme than ion-exchange carriers after bio-polishing. 


\subsection{Bio-stoning or denim bio-wash}

Denim garments are prepared from a warp face cotton fabric in which indigo dyes are used to dye warp yarn. To impart a worn look to them, the garments are subjected to wash treatment. During the process of stone-washing, the strong mechanical abrasive action of the pumice stones on fibre surfaces leads to non-homogeneous removal of dye from the fabric and reveals the white interior of the yarn, which causes the faded, worn and aged appearance (Cavaco-Paulo 1998; Bhat 2000; Choudhury 2014). However, denim washing with natural pumice stones suffers from some disadvantages. For example, the overload of pumice stones can cause severe physical damage to equipment and garments, and the stones give rise to particulate materials, which lead to the clogging of the machine drainage passage and sewer lines (Pazarlioglu et al. 2005; Yu et al. 2013).

Denim bio-washing has become one of the most successful and reliable enzyme-based systems in the textile industry owing to extensive research in recent times (Belghith et al. 2001; Yu et al. 2013, Cavaco-Paulo 1998). The application of enzymes in the form of microbial cellulases revolutionized denim washing by replacing stonewashing in the 1980s and nowadays more than 80 per cent of denim finishers use either cellulases or a combination of stones and cellulases to produce a worn appearance on denim (Araujo et al. 2008; Choudhury 2014). Cellulases remove indigo dye from the surface of the fibre in a non-homogeneous manner, a process known as 'biostoning' (Bhat 2000: 366.; Belghith et al. 2001: 257.). Cellulases have the ability to produce the same desired effect with gentler and much less mechanical means, reducing or even eliminating the use of stones. Therefore, enzymatic processes cause less damage to the garment and machines, 
increase productivity and generate less pumice dust in the laundry environment (Araujo et al. 2008; Choudhury 2014; Shahid et al. 2016).

For the purpose of denim finishing, a variety of cellulases with distinctive properties and actions are available. They are either used singly or in combination to achieve a specific desired appearance in the finishing process. They vary in their temperature requirements for optimal activity and range over $30^{\circ}-60^{\circ} \mathrm{C}$. They also differ in $\mathrm{pH}$ for their intended application and are classified as acid ( $\mathrm{pH}$ 4.5-5.5), neutral ( $\mathrm{pH}$ 6.6-7) or alkali ( $\mathrm{pH}$ 9-10) cellulases (Bhat 2000; Araujo et al. 2008).

A major problem in denim finishing is the back-staining, re-deposition of released indigo in the process of stone-washing onto white portions of denim garments. Ideal biostoning would achieve high abrasion with low back staining. Back staining is attributed to the high-affinity interaction between indigo and cellulase enzyme and strong binding of cellulases to cotton celluloses (Madhu and Chakraborty 2017). Acid cellulases possess a higher affinity towards indigo than neutral ones. For this reason, neutral and endoglucanse rich cellulases are preferred to achieve better softening and indigo removal from denims (Araujo et al. 2008; Mojsov 2014). In addition, laccases are used as an eco-friendly alternative to the traditional chemical process. A number of solid laccase formulations are now commercially available for textile wet processing. Recently, the bio-desizing and bio-washing of denim garments were carried out in a one-step method with amylase, cellulase and laccase. The garments did not show any remarkable colour change when compared to the desized samples treated with cellulase and laccase. However, the treated fabrics with three enzymes showed lower back-staining with reasonable abrasion resistances up to 10,000 cycles. This was further improved by incorporating other enzymes such as lipase to improve the quality of desizing and for less colour reduction of denim garments. Furthermore, the use of 
chemical softeners could enhance some other characteristics of the garments, specially softness (Maryan and Montazer 2013).

\section{Conclusion}

Biotechnological progress has opened many windows for sustainable development (Petruzzelli et al. 2015; Coccia 2017). Biotechnology has a strong relationship with sustainability in textile manufacturing with the incorporation of industrial-scale enzymes and their related processes. We can view sustainable textile development as processes where the needs of the present manufacturing are met without reducing the opportunity for future incorporation of greener production systems. In this respect, sustainable development encompasses both harmony and synergy in the utilization of resources, the process of investment and technological development. The ultimate objective is to increase the opportunity to meet both current and future needs in an efficient and responsible manner (Broman and Robèrt 2017). In addition, industrial sustainability takes into account sustainable manufacturing and processing with the objective of ensuring environmental and social sustainability (Turker and Altuntas 2014). However, an industry is deemed sustainable when it can assure that the present demands are met without harming the potential for meeting future generations' needs.

\section{Environmental and market implications}

Biotechnology can ensure greener processes in the textile industry because biotechnologypowered manufacturing and processing systems, essentially enzymatic textile processing, use less materials and energy. It guarantees reduced greenhouse gas emission, less dependence on non- 
renewable resources and increased use of renewable resources (Gavrilescu 2010). Biotechnologyfuelled sustainable products, such as textile enzymes, are better performing, more profitable, durable, less toxic, easily recyclable and biodegradable in the environment (Bolis et al. 2017). In the current competitive and challenging business environment, enzymatic biotechnology is promising in terms of enhancing sustainability concepts in the textile manufacturing supply chain. This enables organizations to achieve a 'competitive position' in the world market by replacing chemical-based processing (Ansari and Kant 2017). By focusing on biotechnology, organizations have adopted sustainable supply chain management (SSCM). SSCM is an integration of three facets of sustainable development: economic contribution, social performance and environmental performance (Khodakarami et al. 2015). The scope for the application of biotechnology to textile industrial processes results in opportunities for assessing frameworks for addressing economic, societal and environmental challenges, including sustainable development, cost minimization and business competitiveness (Ribeiro and Shapira 2018).

Biotechnology has used enzymes as an alternative to the harmful chemicals in the textile industry. Enzymes are found in naturally occurring micro-organisms, such as bacteria, fungi and yeast. Enzymes are protein molecules that act as catalysts and are found in micro-organisms, such as bacteria, fungi and yeast. Use of enzyme has created scope for biotechnology to reduce costs in the manufacturing process, with reduced consumption of water, electricity and fuels, and improvement in the final product. This contributes to business competitiveness. Apart from the cleaning process, textile enzyme is being used in the treatment of cotton fibres. Enzymes enable a faster and softer treatment process, which results in less chemical and energy consumption (OECD 2011). 


\section{Limitations and further research}

This article has some limitations linked to the fact that it is literature based. In addition, despite our effort to simplify the complex scientific data examined, there remain lots of key terminologies that may not be accessible to a number of stakeholders in the developing world. Consequently, we suggest that future research consider a glossary of terms to facilitate reading by stakeholders who are unfamiliar with some key scientific and technological terms. We also see the need for future research to be more empirical in nature and evaluate the extent of the implementation of biotechnologies in textile processing in developing countries and emerging issues, which will enable science to take corrective actions or seek improvements in such technologies.

\section{Acknowledgement}

The work is funded by the Commonwealth Rutherford fellowship.

\section{References}

Abou-Okeil, A., El-Shafie, A. and El-Zawahry, M. M. (2010), 'Eco-friendly laccase hydrogen peroxide/ultrasound-assisted bleaching of linen fabrics and its influence on dyeing efficiency', Ultrasonics Sonochemistry, 17:2, pp. 383-90.

Agrawal, P. B., Nierstrasz, V. A. and Warmoeskerken, M. M. C. G. (2008), 'Role of mechanical action in low temperature cotton scouring with $F$. solani pisi cutinase and pectate lyase', Enzyme and Microbial Technology, 42:6, pp. 473-82. 
Aly, A. S., Sayed, S. H. M. and Zahran, M. K. (2010), 'One-step process for enzymatic desizing and bioscouring of cotton fabrics', Journal of Natural Fibers, 7:2, pp. 71-92.

Ando, S., Ishida, H., Kosugi, Y. and Ishikawa, K. (2002), 'Hyperthermostable endoglucanase from Pyrococcus horikoshii', Applied and Environmental Microbiology, 68:1, pp. 430-33.

Anis, P., Davulcu, A. and Eren, H. A. (2009), 'Enzymatic pre-treatment of cotton Part 2: Peroxide generation in desizing liquor and bleaching', Fibres and Textiles in Eastern Europe, 17:2, pp. 87-90.

Ansari, Z. N. and Kant, R. (2017), 'A state-of-art literature review reflecting 15 years of focus on sustainable supply chain management', Journal of Cleaner Production, 142:4, pp. 2524-43.

Arai, T., Freddi, G., Innocenti, R. and Tsukada, M. (2004), 'Biodegradation of Bombyx mori silk fibroin fibers and films', Journal of Applied Polymer Science, 91:4, 2383-90.

Araujo, R., Casal, M. and Cavaco-Paulo, A. (2008), 'Application of enzymes for textile fibres processing', Biocatalysis and Biotransformation, 26:5, pp. 332-49.

Auterinen, A.-L. (2011), 'Enzymatic textile bleaching compositions and methods of use thereof', U.S. Patent Application 14/220, 436. 
Bahtiyari, M. I. and Duran, K. (2010), 'Usage of commercial cellulases in biopolishing of viscose fabrics', Tekstil vs Konfeksiyon, 20:1, pp. 57-64.

Bai, G., Fu, K. L., Jin, N. Y., Zhu, L. L., Chai, H. M., and Lu, D. N. (2012), 'Bio-polishing of cotton fabrics with cellulase', Advanced Materials Research, 468:471, pp. 46-49.

Basto, C., Tzanov, T. and Cavaco-Paulo, A. (2007), 'Combined ultrasound-laccase assisted bleaching of cotton', Ultrasonics Sonochemistry, 14:3, pp. 350-54.

Belghith, H., Ellouz-Chaabouni, S. and Gargouri, A. (2001), 'Biostoning of denims by Penicillium occitanis (Pol6) cellulases', Journal of Biotechnology, 89:2-3, pp. 257-62.

Bertoldo, C. and Antranikian, G. (2002), 'Starch-hydrolyzing enzymes from thermophilic archaea and bacteria', Current Opinion in Chemical Biology, 6:2, pp. 151-60.

Bhat, M. K. (2000), Cellulases and related enzymes in biotechnology', Biotechnology Advances, 18:5, pp. 355-83. 
Bolis, I., Morioka, S. N. and Sznelwar, L. I. (2017), 'Are we making decisions in a sustainable way? A comprehensive literature review about rationalities for sustainable development', Journal of Cleaner Production, 145:2017, pp. 310-22.

Broman, G. I. and Robèrt, K. H. (2017), 'A framework for strategic sustainable development', Journal of Cleaner Production, 140:2017, pp. 17-31.

Buchert, J., Pere, J., Puolakka, A., and Nousiainen, P. (2000), 'Scouring of cotton with pectinases, proteases, and lipases', Textile Chemist and Colorist \& American Dyestuff Reporter, 32:5, pp. 48-52.

Cavaco-Paulo, A. (1998), 'Mechanism of cellulase action in textile processes', Carbohydrate Polymers, 37:3, pp. 273-77.

Choudhury, A. K. R. (2014), 'Sustainable textile wet processing: Applications of enzymes', in S. S. Muthu (ed.), Roadmap to Sustainable Textiles and Clothing, Singapore: Springer, pp. 20338.

Coccia, M. (2017), 'The source and nature of general purpose technologies for supporting next K-waves: Global leadership and the case study of the US Navy's mobile user objective system', Technological Forecasting and Social Change, 116, pp. 331-39. 
Costa, S. A., Tzanov, T., Carneiro, F., Gübitz, G. M., and Cavaco-Paulo, A. (2002), 'Recycling of textile bleaching effluents for dyeing using immobilized catalase', Biotechnology Letters, 24:3, pp. 173-76.

Csiszár, E., Losonczi, A., Szakács, G., Rusznák, I., Bezúr, L., and Reicher, J. (2001), ‘Enzymes and chelating agent in cotton pretreatment', Journal of Biotechnology, 89:2-3, pp. 271-79.

Dana, L. P. (2015), 'Qualitative research revisited: Epistemology of a comprehensive approach', International Journal of Entrepreneurship and Small Business, 26:2, pp. 154-70.

Dana, L. P. and Dana, T. E. (2005), 'Expanding the scope of methodologies used in entrepreneurship research', International Journal Entrepreneurship and Small Business, 2:1, pp. $79-88$.

Delcheva, G. (2007), 'Immobilization of Aspergillus Niger pectinase on polyacrylonitrile copolymer membrane', Trends in Applied Sciences Research, 2:5, pp. 419-25.

Diderichsen, B. (1995), 'A new desizing enzyme shows the changing nature of enzyme production', Journal of Biotechnology, 38:2, pp. 196-97. 
Dincer, A. and Telefoncu, A. (2007), 'Improving the stability of cellulose by immobilizationon modified polyvinyl alcohol-coated chitosan beads', Journal of Molecular Catalysis B: Enzymatic, 45:1-2, pp. 10-14.

Farooq, A., Ali, S., Abbas, N., Fatima, G. A., and Ashraf, M. A. (2013), 'Comparative performance evaluation of conventional bleaching and enzymatic bleaching with glucose oxidase on knitted cotton fabric', Journal of Cleaner Production, 42:2013, pp. 167-71.

Gavrilescu, M. (2010), 'Environmental biotechnology: Achievements, opportunities and challenges', Dynamic Biochemistry, Process Biotechnology and Molecular Biology, 4:1, pp. $1-36$.

Gonçalves, I., Herrero-Yniesta, V., Arce, I. P., Castañeda, M. E., Cavaco-Paulo, A. and Silva, C. (2014), 'Ultrasonic pilot-scale reactor for enzymatic bleaching of cotton fabrics', Ultrasonics Sonochemistry, 21:4, pp. 1535-43.

Gulrajani, M. L. (1992), 'Degumming of silk', Review of Progress in Colouration and Related Topics, 22:1, pp. 79-89. 
Gulrajani, M. L., Agarwal, R., Grover, A. and Suri, M

(2000), 'Degumming of silk with lipase and protease', Indian Journal of Fibre and Textile Research, 25:1, pp. 69-74.

Gwozdz, W., Steensen Nielsen, K. and Müller, T. (2017), 'An environmental perspective on clothing consumption: Consumer segments and their behavioural patterns', Sustainability, 9:5, pp. 762-89.

Hadzhiyska, H., Calafell, M., Gibert, J. M., Dagà, J. M. and Tzanov, T.

(2006), 'Laccase assisted dyeing of cotton’, Biotechnology Letters, 28:10, pp. 755-59.

Hardin, I. R. (2010), ‘Enzymatic treatment versus conventional chemical processing of cotton', in V. A. Nierstrasz and A. Cavaco-Paulo (eds), Advances in Textile Biotechnology, Cambridge: Woodhead Publishing Limited, pp. 132-49.

Hartzell, M. M. and You-Lo, H. (1998), 'Pectin-degrading enzymes for scouring cotton', in K.E. L. Eriksson and A. Cavaco-Paulo (eds), Enzyme Applications in Fiber Processing, Washington, DC:

American Chemical Society, no. 687, pp. 212-27. 
Hebeish, A., Ramadan, M. A., Hashem, M., Sadek, B. and Abdel-Hady, M.

(2013), 'New development for combined bioscouring and bleaching of cotton-based fabrics', Research Journal of Textile and Apparel, 17:1, pp. 94-103.

Hirsh, S. L., Bilek, M. M. M., Nosworthy, N. J., Kondyurin, A., Dos Remedios, C. G. and McKenzie, D. R.

(2010), 'A comparison of covalent immobilization and physical adsorption of a cellulase enzyme mixture', Langmuir, 26:17, pp. 14380-88.

Hossain, S. and Uddin, K. (2011), 'Comparative analysis between conventional pretreatment and bio-preparation', International Journal of Engineering \& Technology, 11:3, pp. 16-21.

Ibrahim, N. A., El-Badry, K., Eid, B. M. and Hassan, T. M.

(2011), 'A new approach for biofinishing of cellulose-containing fabrics using acid cellulases', Carbohydrate Polymers, 83:1, pp. 116-21.

Ibrahim, N. A., El-Hossamy, M., Morsy, M. S. and Eid, B. M. 
(2004), 'Optimization and modification of enzymatic desizing of starch size', Polymer-Plastics Technology and Engineering, 43:2, pp. 519-38.

Ismal, O. E. (2008), 'Influence of wax and pectin removal on cotton absorbency',AATCC Review, 8:6, pp. 37-42.

Jørgensen, M.S., Hansen, A.G., Andersen, M.M., Jørgensen, U., Falch, M., Pedersen, T.T., Wenzel, H., Rasmussen, B., Olsen, S.I. and Willum, O

(2006), Green Technology Foresight about Environmentally Friendly Products and Materials Challenges from Nanotechnology, Biotechnology and ICT, Kongens Lyngby:

Working report 34, Danish Environmental Protection Agency.

Kalantzi, S., Mamma, D., Kalogeris, E. and Kekos, D.

(2010), 'Improved properties of cotton fabrics treated with lipase and its combination with pectinase', Fibres and Textiles in Eastern Europe, 18:5, pp. 86-92.

Karapinar, E. and Sariisik, M. O. (2004), 'Scouring of cotton with cellulases, pectinases and proteases', Fibres and Textiles in Eastern Europe, 12:3, pp. 79-82. 
Khemakhem, B., Ali, M.B., Aghajari, N., Juy, M., Haser, R. and Bejar, S.

(2008), 'Engineering of the $\alpha$-amylase from Geobacillus stearothermophilus US100 for detergent incorporation', Biotechnology and Bioengineering, 102:2, pp. 380-89.

Khodakarami, M., Shabani, A., Saen, R.F. and Azadi, M.

(2015), 'Developing distinctive two-stage data envelopment analysis models: An application in evaluating the sustainability of supply chain management', Measurement, 70, pp. 62-74.

Kim, S., Moldes, D. and Cavaco-Paulo, A. (2007), 'Laccase for enzymatic colouration of unbleached cotton', Enzyme and Microbial Technology, 40:7, pp. 1788-93.

Kumar, P. S. and Gunasundari, E. (2018), 'Sustainable wet processing - an alternative source for detoxifying supply chain in textiles', in S. S. Muthu (ed.), Detox Fashion Sustainable Chemistry and Wet Processing, Singapore: Springer, pp. 37-60.

Lantto, R., Schönberg, C., Buchert, J. and Heine, E.

(2004), 'Effects of laccase-mediator combinations on wool', Textile Research Journal, 74:8, pp. 713-17. 
Li, M. and Hinks, D. (2012), 'An environmentally benign approach to cotton preparation: One bath enzymatic desizing, scouring \& activated bleaching', 2012 Proceedings of AATCC International Conference, $21^{\text {st }}-23^{\text {rd }}$ March, 2012: Hilton University Place, Charlotte, NC, USA, pp. $19-28$

Li, S., Yang, X., Yang, S., Zhu, M. and Wang, X.

(2012), 'Technology prospecting on enzymes: Application, marketing and engineering', Computational and Structural Biotechnology Journal, 2:3, p. e201209017.

Li, T., Wang, N., Li, S., Zhao, Q., Guo, M. and Zhang, C.

(2007), 'Optimization of covalent immobilization of pectinase on sodium alginate support', Biotechnology Letters, 29:9, pp. 1413-16.

Li, Y. and Hardin, I. R. (1997), 'Enzymatic scouring of cotton: Effects on structure and properties', Textile Chemist and Colourist, 29:8, pp. 71-76.

Madhu, A. and Chakraborty, J. N. (2017), 'Developments in application of enzymes for textile processing', Journal of Cleaner Production, 145:2017, pp. 114-33. 
Maiti, S., Kulkarni, K. and Adivarekar, R. V. (2018), 'Biotechnology in textile wet processing', Biomedical Engineering and Biotechnology, 2:1, pp. 7-13.

Maryan, A. S. and Montazer, M. (2013), 'A cleaner production of denim garment using one step treatment with amylase/cellulase/laccase', Journal of Cleaner Production, 57:2013, pp. 32026.

Mojsov, K. (2011), 'Application of enzymes in the textile industry; a review', II International Congress 'Engineering, Ecology and Materials in the Processing Industry', 9th-11th March, 2011: Jahorina, Bosnia and Herzegovina, pp. 230-39.

(2014), 'Biopolishing enzymes and their applications in textiles: A review', Tekstilna Industrija, 61:2, pp. 20-24.

OECD (2001), 'The application of biotechnology to industrial sustainability-a Primer', Organization for Economic Co-operation and Development (OECD) 2001. (2011), 'Industrial biotechnology and climate change: Opportunities and challenges', Organization for Economic Co-operation and Development (OECD) 2011. 
Opwis, K., Mayer-Gall, T., Schollmeyer, E., Dammer, C., Titscher, T., Nickisch-Hartfiel, A., Grün, O., Spurk, C., Schloderer, C., Köppe, A. and Dörfler, C.

(2010), 'Generation of methane from textile desizing liquors', Engineering in Life Sciences, 10:4, pp. 293-96.

Parmar, N. and Shukla, S. R. (2018), 'Enzymes - biobased economy for textile industry', Colourage, LXIII:4, p. 46

Pazarlioglu, N. K., Sariisik, M. and Telefoncu, A. (2005), 'Treating denim fabrics with immobilized commercial cellulases', Process Biochemistry, 40:2, pp. 767-71.

Pereira, L., Bastos, C., Tzanov, T., Cavaco-Paulo, A. and Guebitz, G. M. (2005), 'Environmentally friendly bleaching of cotton using laccases', Environmental Chemistry Letters, 3:2, pp. 66-69.

Pere, J., Puolakka, A., Nousiainen, P. and Buchert, J.

(2001), 'Action of purified Trichoderma reesei cellulases on cotton fibers and yarn', Journal of Biotechnology, 89:2-3, pp. 247-55. 
Petruzzelli, A. M., Rotolo, D. and Albino, V. (2015), 'Determinants of patent citations in biotechnology: An analysis of patent influence across the industrial and organizational boundaries', Technological Forecasting and Social Change, 91:2015, pp. 208-21.

Presa, P. and Tavcer, P. F. (2008), 'Bio-scouring and bleaching of cotton with pectinase enzyme and peracetic acid in one bath', Colouration Technology, 124:1, pp. 36-42.

Ramadan, A. R. (2008), 'Characterization of biobleaching of cotton/linen fabrics', Journal of Textile and Apparel, Technology and Management, 6:1, pp. 1-12.

Regan, I. (1962), 'Enzymes and their application in textile processing, especially desizing', Journal of the Society of Dyers and Colourists, 78:11, pp. 533-542.

Ribeiro, B. and Shapira, P. (2018), 'Anticipating governance challenges in synthetic biology: Insights from biosynthetic menthol', Technological Forecasting and Social Change, 139:2019, pp. 311-320. 
Romo-Sánchez, S., Camacho, C., Ramirez, H.L. and Arévalo-Villena, M (2014), 'Immobilization of commercial cellulase and xylanase by different methods using two polymeric supports', Advances in Bioscience and Biotechnology, 5:06, pp. 517-26.

Sahin, U. K. and Gursoy, N. C. (2005), 'Low temperature acidic pectinase scouring for enhancing textile quality', AATCC Review, 5:1, pp. 27-30.

Sangwatanaroj, U., Choonukulpong, K. and Ueda, M. (2003), 'Cotton scouring with pectinase and lipase/protease/cellulase', AATCC Review, 3:5, pp. 17-20.

Saravanan, D., Prakash, A.A., Jagadeeshwaran, D., Nalankilli, G., Ramachandran, T. and Prabakaran, C.

(2011), 'Optimization of thermophile bacillus licheniformis $\alpha$-amylase desizing of cotton fabrics', Indian Journal of Fibre \& Textile Research, 36: September, pp. 253-58.

Saravanan, D., Lakshmi, S.N., Raja, K.S. and Vasanthi, N.S

(2013), 'Biopolishing of cotton fabric with fungal cellulase and its effect on the morphology of cotton fibres', Indian Journal of Fibre \& Textile Research, 38: June, pp. 156-60. 
Saravanan, D., Ramachandran, T., Rajendran, S. and Raajesh, E.M

(2008), 'Influence of mechanical agitations in enzyme assisted processing', Man-made Textiles in India, 51:9, pp. 313-16.

Saravanan, D., Vasanthi, N. S. and Ramachandran, T. (2009), 'A review on influential behaviour of biopolishing on dyeability and certain physico-mechanical properties of cotton fabrics', Carbohydrate Polymers, 76:1, pp. 1-7.

Sarmiento, F., Peralta, R. and Blamey, J. M. (2015), 'Cold and hot extremozymes: Industrial relevance and current trends', Frontiers in Bioegnineering and Biotechnology, 3: October, p. 148.

Saxena, S., Raja, A. S. M. and Arputharaj, A. (2017), 'Challenges in sustainable wet processing of textiles', in S. S. Muthu (ed.), Textiles and Clothing Sustainability, Singapore: Springer, pp. 43-79.

Shahid, M., Mohammad, F., Chen, G., Tang, R.C. and Xing, T. (2016), 'Enzymatic processing of natural fibres: White biotechnology for sustainable development', Green Chemistry, 18: 8, pp. $2256-2281$. 
Sharma A. and Satyanarayana, T. (2013), 'Microbial acid-stable $\alpha$-amylases: Characteriztics, genetic engineering and applications', Process Biochemistry, 48: 2, pp. 201-11.

Shen, J. (2009), 'Wool finishing and the development of novel finishes', in N. A. G. Johnson and I. M. Russell (eds), Advances in Wool Technology, Cambridge: Woodhead Publishing Limited, pp. 171-92.

(2010), 'Enzymatic treatment of wool and silk fibres', in V. A. Nierstrasz and A. CavacoPaulo (eds), Advances in Textile Biotechnology, Cambridge: Woodhead publishing Limited, pp. 171-92.

Shen, J. and Smith, E. (2015), 'Enzymatic treatments for sustainable textile processing', in R. Blackburn (ed.), Sustainable Apparel: Production, Processing and Recycling, Cambridge: Woodhead Publishing Limited, pp. 119-34.

Siddiqui, A. S. (2015), 'Some like it hot, some like it cold: Temperature dependent biotechnological applications and improvements in extremophilic enzymes', Biotechnology Advances, 33:8, pp. 1912-22. 
Silva, C., Cavaco-Paulo, A. and Nierstrastrasz, V. A. (2010), 'Chapter 4 enzymatic hydrolysis and modification of core polymer fibers for textile and other applications in advances in textile biotechnology', in A. Cavaco-Paulo and V. A. Nierstrastrasz (eds), Advances in Textile Biotechnology, Cambridge: Woodhead Publishing Limited, pp. 77-97.

Silva, C.J., Zhang, Q., Shen, J. and Cavaco-Paulo, A. (2006), 'Immobilization of proteases with a water soluble-insoluble reversible polymer for treatment of wool', Enzyme and Microbial Technology, 39:4, pp. 634-40.

Sojka-Ledakowicz, J., Joanna, L. and Pyc, R. (2006), 'Integrated enzymatic pre-treatment of cotton fabrics', Journal of Natural Fibers, 3:2-3, pp. 199-207.

Solbak, A.I., Richardson, T.H., McCann, R.T., Kline, K.A., Bartnek, F., Tomlinson, G., Tan, X., Parra-Gessert, L., Frey, G.J., Podar, M. and Luginbühl, P.

(2005), 'Discovery of pectin degrading enzymes and directed evolution of a novel pectate lyase for processing cotton fabric', The Journal of Biological Chemistry, 280:10, pp. 9431-38.

Spicka, N. and Tavcer, P. F. (2013a), 'New combined bio-scouring and bio-bleaching process of cotton fabrics', Materials and Technology, 47:4, pp. 409-12. 
(2013b), 'Complete enzymatic pre-treatment of cotton fabric with incorporated bleach activator', Textile Research Journal, 83:6, pp. 566-73.

Strong, P. J. and Claus, H. (2011), 'Laccase: A review of its past and its future in bioremediation', Critical Reviews in Environmental Science and Technology, 41:4, pp. 373-434.

Traore, M. K. and Buschle-Diller, G. (2000), 'Environmentally friendly scouring process', Textile Chemist and Colorist \& American Dyestuff Reporter, 32:12, pp. 40-43.

Turker, D. and Altuntas, C. (2014), 'Sustainable supply chain management in the fast fashion industry: An analysis of corporate reports', European Management Journal, 32:5, pp. 83749.

Tzanov, T., Basto, C., Gübitz, G.M. and Cavaco-Paulo, A.

(2003a), 'Laccases to improve the whiteness in a conventional bleaching of cotton', Macromolecular Materials and Engineering, 288:10, pp. 807-10.

Tzanov, T., Silva, C.J., Zille, A., Oliveira, J. and Cavaco-Paulo, A. 
(2003b), 'Effect of some process parameters in enzymatic dyeing of wool', Applied Biochemistry and Biotechnology, 111:1, pp. 1-13.

Uddin, M. G. (2010), 'Determination of weight loss of knitfabrics in combined scouring-bleaching and enzymatic treatment', Journal of Innovative and Developmental Strategy, 4:1, pp. 18-21.

Ul-Haq, N. and Nasir, H. (2012), 'Cleaner production technologies in desizing of cotton fabric', The Journal of The Textile Institute, 103:3, pp. 304-10.

Vigneswaran, C., Ananthasubramanian, M., Anbumani, N. and Kandhavadivu, P.

(2013), 'Ecofriendly approach to improve pectinolytic reaction and process optimization of bioscouring of organic cotton textiles', Journal of Engineered Fibers and Fabrics, 8:2, pp. $121-33$.

Vilchez, S., Jovancic, P. and Erra, P. (2010), 'Influence of chitosan on effects of proteases on wool fibres', Fibers and Polymers, 11:1, pp. 28-35.

Wang, Q., Fan, X., Hua, Z., Gao, W. and Chen, J. 
(2007a), 'Influence of combined enzymatic treatment on one-bath scouring of cotton knitted fabrics', Biocatalysis and Biotransformation, 25:1, pp. 9-15.

(2007b), 'Degradation kinetics of pectins by an alkaline pectinase in bioscouring of cotton fabrics', Carbohydrate Polymers, 67:4, pp. 572-75.

Yin, H., Su, Z.L., Shao, H., Cai, J., Wang, X. and Yin, H.

(2013), 'Immobilization of cellulase onmodified mesoporous silica shows improved thermal stability and reusability', African Journal of Microbiological Research, 7:2013, pp. 3248-53.

Yu, Y., Yuan, J., Wang, Q., Fan, X., Ni, X., Wang, P. and Cui, L.

(2013), 'Cellulase immobilization onto the reversibly soluble methacrylate copolymer for denim washing', Carbohydrate Polymers, 95:2, pp. 675-80.

Table 1: Application of enzymes in textile processing and their mechanism of actions. 


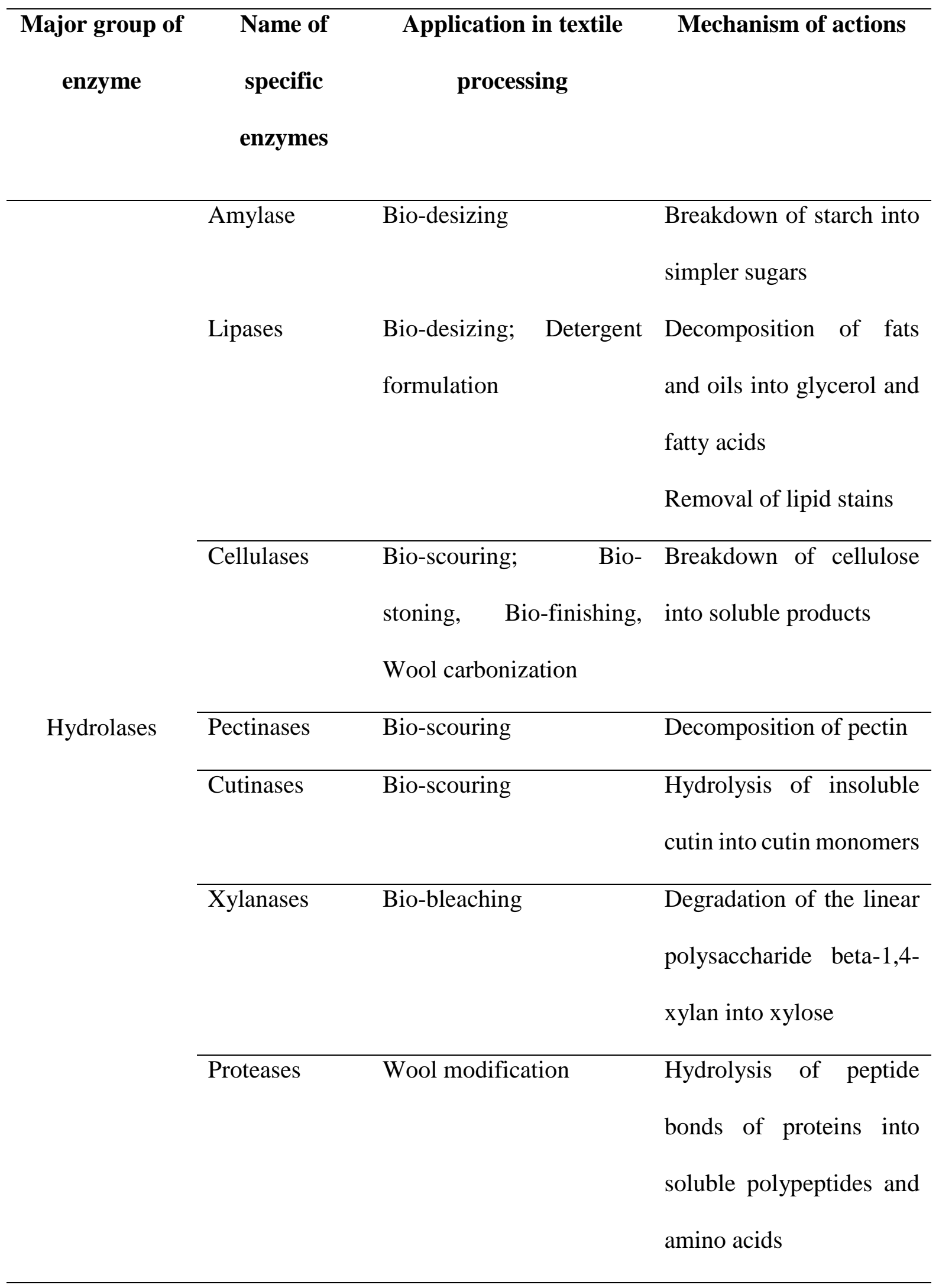




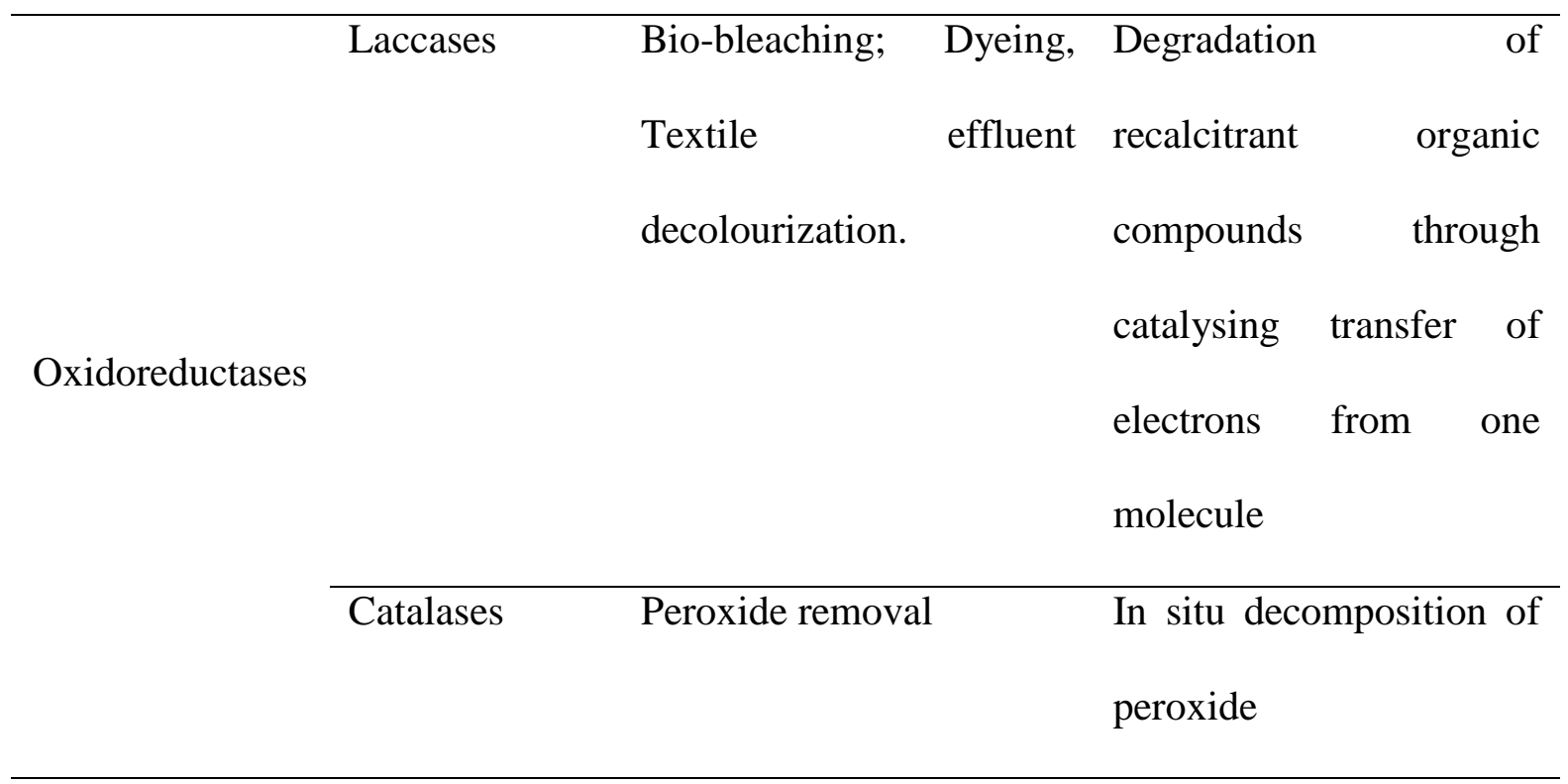

\section{Contributor details}

Mahfuzur Rahman is senior lecturer at Lincoln International Business School, University of Lincoln, UK. His current academic and research interests are in the area of entrepreneurship and innovation, with a focus on sustainability. Investigating the potential environment-friendly manufacturing, such as adoption of textile enzymes, for a sustainable future motivates his most recent research works. Dr Rahman's research projects are funded by the Commonwealth 
Commission, the British Council and UNIDO. He is an active team member of the University of Lincoln UNESCO Chair on Responsible Foresight for Sustainable Development.

Dieu Hack-Polay is an associate professor at Lincoln International Business School, University of Lincoln, UK. He specializes in organizational behaviour \& management in the Lincoln International Business School. He worked for several years in various sectors of activity including the voluntary sector and local government as a human resources and training practitioner in the United Kingdom. He also has several years of experience as an academic. He has worked for various institutions in the UK, Canada and China. Dieu obtained the Doctor of Philosophy (Ph.D.) at the University of Surrey and the Doctor of Education (Ed.D.) in leadership and management at the University of Lincoln.

Prof. Md Morsaline Billah is a visiting academic at Lincoln International Business School, University of Lincoln, UK, supported by the Commonwealth Rutherford fellowship. He is a Professor of Biotechnology at Biotechnology and Genetic Engineering Discipline, Khulna University, Khulna, Bangladesh. He obtained his B.Sc. in biotechnology (2000) from the same institution and Ph.D. (2008) from University of Leeds, UK. His research interests are in Biotechnology Business, Biosensors, Bionanotechnology and Natural Products Biotechnology.

Prof. Noor Un Nabi is a visiting professor, International SEPT Programme, Leipzig University, Germany. He works as a professor in the business administration discipline, Khulna University, Khulna, Bangladesh. His initial training came from the business administration discipline, Khulna University, where he obtained a Bachelor of Business Administration (BBA) degree in 
1996 and later, he obtained a Master of Small Business Studies (MSBS) (2006) degree and a

Ph.D. in International Business \& Entrepreneurship (2010) from Leipzig University, Germany. His research interests include internationalization of firms and global value chain.

Contact:

Mahfuzur Rahman and Dieu Hack-Polay, Lincoln International Business School, University of Lincoln, Brayford Pool, Lincoln LN6 7TS, UK.

E-mail: $\underline{\text { marahman@lincoln.ac.uk }}$

E-mail: dhackpolay@lincoln.ac.uk

https://orcid.org/0000-0002-3386-9613

https://orcid.org/0000-0002-1038-5018

Md Morsaline Billah, Lincoln Business School, University of Lincoln, Brayford Pool, Lincoln, Lincolnshire, LN6 7TS, UK.

Biotechnology and Genetic Engineering Discipline, Khulna University, Khulna-9208, Bangladesh.

E-mail: $\underline{\text { mbillah@lincoln.ac.uk; morsaline@bge.ku.ac.bd }}$ https://orcid.org/0000-0003-2125-9233

Noor Un Nabi, Business Administration Discipline, Khulna University, Khulna-9208, Bangladesh.

E-mail: nnabi.m@gmail.com

https://orcid.org/0000-0002-5441-2532 
